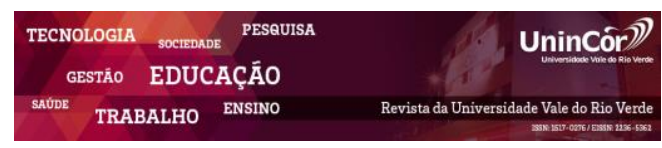

Revista da Universidade Vale do Rio Verde ISSN: 1517-0276 / EISSN: 2236-5362 Vol. 16 | n. 1 | Ano 2018

Daniela Cristina de Macedo Vieira Universidade Federal de Alfenas danicmvieira1@gmail.com

Josimary de Morais Vasconcelos Universidade Federal de Alfenas josimv@ hotmail.com

Patrícia Aparecida Fernandes Alves Universidade Federal de Alfenas patriciaalves.nat@gmail.com

Thalita Francieli Pereira Universidade Federal de Alfenas thalita_tfp@hotmail.com

\section{EFFECT OF SIMVASTATIN ON THE GROWTH INHIBITION OF Candida albicans}

\begin{abstract}
Yeasts of the Candida genus often interact in a commensal coloniser of humans. However, in certain conditions they can cause infections such as superficial or systemic candidiasis, which are responsible for high mortality rates because of ineffective diagnoses and treatments. The mechanisms associated with the virulence of Candida albicans must be understood since they have acquired growing importance due to their increased resistance to drugs such as Fluconazole and Amphotericin B, both commonly used in therapeutic hospital routines. The present study evaluated the sensibility of isolated $C$. albicans to simvastatin, which acts on the ergosterol of the plasma membrane of this fungus. The sensitivity profile of the isolated C. albicans ATCC 90028 to simvastatin was determined by the agar diffusion methodology. The concentration of simvastatin used ranged from 78 to $2500 \mu \mathrm{g} \cdot \mathrm{mL}^{-1}$. The results obtained demonstrated that simvastatin has great potential for being used against $C$. albicans.
\end{abstract}

Keywords: Simvastatin. Antifungal Action. Candida albicans. Sensibility. Fluconazole.

\section{EFEITO DA AÇÃO DA SINVASTATINA NA INIBIÇÃO DO CRESCIMENTO DE Candida albicans}

\section{RESUMO}

Leveduras do gênero Candida muitas vezes interagem como colonizadoras comensais de humanos. No entanto, em certas condições, podem causar infecções, como a candidíase superficial ou sistêmica, que são responsáveis por altas taxas de mortalidade devido à diagnósticos e tratamentos ineficazes. Os mecanismos associados à virulência de Candida albicans devem ser entendidos, uma vez que adquiriram importância crescente devido à sua maior resistência a medicamentos como Fluconazole e Anfotericina B, ambos comumente usados em rotinas hospitalares terapêuticas. O presente estudo avaliou a sensibilidade de isolado de C. albicans à sinvastatina, que atua no ergosterol da membrana plasmática desse fungo. O perfil de sensibilidade do C. albicans isolado ATCC 90028 a sinvastatina foi determinado pela metodologia de difusão em ágar. A concentração de sinvastatina utilizada variou de 78 a $2500 \mu \mathrm{g} . \mathrm{mL}-1$. Os resultados obtidos demonstraram que sinvastatina tem um grande potencial para ser usado contra $C$. albicans.

Palavras-chave: Sinvastatina. Atividade antifúngica. Candida albicans. Sensibilidade. Fluconazol. 


\section{INTRODUCTION}

The Candida genus is formed by almost 200 species, and approximately 10 are responsible for infections in man and cause superficial or invasive mycoses. The most important species is C. albicans accounting for about 50 to $70 \%$ of all invasive infections by the Candida genus (TORRES; LIMA; UEDA, 2016).

Until the mid-twentieth century, reports of invasive yeast infections of Candida genus were scarce, but for the past 20 years, the incidence of systemic infections has greatly increased (DE MELLO et al, 2017). The increase in the frequency of infections by Candida species in the last decades has made candidiasis an infection present in hospitals (SUTTON et al, 2017)

Triazolic agents, such as fluconazole and itraconazole, which are administered orally or intravenously in hospital use, are the drugs most used in the treatment of mycoses and are useful in the prophylaxis of patients at risk of developing fungal infections, as they are less toxic than polyenes (DEL POETA, 2016; AHMAD, 2016). These drugs have good oral acceptance, a low incidence of side effects after being introduced, a new era in the treatment of fungal infections has started (CAMPOY, ADRIO, 2017).

Azole agents interfere in the biosynthesis of ergosterol, the sterol present in the plasma membrane of fungi. Their mechanism of action occurs by inhibiting the enzyme $14 \alpha$-demethylase (14 DM), an important cytochrome P-450 enzyme in the ergosterol biosynthesis route, which cata- lyzes the oxidative removal of the $14 \alpha$-methyl group from lanosterol (ZHANG et al, 2016; NIWA; IMAGAWA, 2016; SUI et al, 2017). Azole, bound to the active site of this enzyme, competes with the substrate for binding). An interruption in ergosterol production in fungi is lethal, as it affects cytokinesis, preventing cell growth and increasing the chances of the membrane collapsing (WARRILOW et al, 2016; CHENGE et al, 2017).

Ergosterol, as well as cholesterol, stabilize and modulate membrane fluidity and permeability, as well as modulate enzymatic activities linked to the membrane and ion channels (ALCAZAR-FUOLI; MELLADO, 2013; LONG et al, 2016). The biochemical route to ergosterol formation is similar to that of cholesterol.

After a long time, it was observed that the treatment with the azoles was failing. Some studies have reported that one of the reasons for this failure was due to the resistance of Candida to antifungal agents (MONROY-PÉREZ et al, 2016; MEIS et al, 2016; LEONARDELLI et al, 2017). This fact warns for need to develop strategies to prevent the spread of the species among fungi, as has already occurred with bacteria, which are now widespread and out of control (Thangamani et al, 2015; ZHANG et al, 2017).

Studies conducted by Rahal et al (2015) have indicated clinical benefits for the use of statins during the treatment of infections and sepsis. Atorvastatin was used intraperitoneally in 
mice infected with $C$. albicans and the effect of this statin was to increase the survival of the mice by inhibition of C. albicans. In 2006 Macreadie, et al had already studied the effects of the two major statins, simvastatin and atorvastatin, on five species of Candida and Aspergillus fumigatus. Statins strongly inhibited the growth of all species except Candida krusei. The antimicrobial effects of statins against various oral and skin microorganisms (THANGAMANI et al, 2015) have also been studied. Simvastatin is most effective against the periodontal pathogens Aggregatibacter actinomycetemcomitans and Porphyromonas gingivalis, and against most dental plaque bacteria, including Streptococcus mutans. Statins also exhibited antiviral properties against human cytomegalovirus, hepatitis B virus and hepatitis $\mathrm{C}$ virus, and have antifungal properties against Candida albicans, Aspergillus fumigatus and Zygomycetes spp (TING; WHITAKER; ALBANDAR, 2016).

New therapeutic strategies are needed to prevent the spread of resistance. Among these strategies, we can highlight the search for new drugs and combinations of drugs with synergic purpose, that is, to perform combinations where the result of this union is better than the action of each drug acting separately (MENEZES et al, 2012).

Statins are drugs used to treat hypercholesterolemia, but may also have some antifungal activity. They act by inhibiting the enzyme 3-hydroxy-3-methylglutaryl reductase (HMG-CoA) and reduce the level of cholesterol synthesis intermediates. In vitro studies have shown that simvastatin inhibits the growth of
Candida spp. In addition, may be useful in the treatment of candidiasis (MENEZES et al, 2012).

Yeasts use the same enzyme pathway, but the end product is ergosterol.

As reported in the studies, statins strongly inhibited the growth of some Candida species and the results then suggested that statins may have utility as antifungal agents and that fungal colonization could be affected by statin therapy (MACREADIE et al., 2006; MENEZES et al, 2012; THANGAMANI et al, 2015; TING; WHITAKER; ALBANDAR, 2016; HENNESSY et al, 2016).

Disk diffusion susceptibility testing is widely used for antibacterial compounds in routine clinical microbiology laboratories, and thus, this concept is attractive for antifungal susceptibility testing. The CLSI (2015) has approved a disk diffusion methodology for the testing of several antifungals (document M44A2).

This study aimed to evaluate the in vitro antimicrobial potential of simvastatin in $C$. albicans and to determine the minimum inhibitory concentration (MIC).

\section{MATERIAL AND METHODS}

For the study was used standard strain of Candida albicans ATCC 90028, belonging to the Department of Microbiology and Immunology of the Federal University of Alfenas, Brazil. The purity and identity of the $C$. albicans strain was confirmed by growth on chromogenic medium and microscopical and biochemical features. 
Disk diffusion and assays were performed strictly according to CLSI (2015) documents M44-A2 of the Clinical and Laboratory Standards Institute. The tests were performed in triplicate and visually read after $24 \mathrm{~h}$ of incubation at $35^{\circ} \mathrm{C}$. The inoculums were prepared obtaining a final concentration of $0.5 \times 10^{8}$ cells $\mathrm{mL}^{-1}$. Two samples of simvastatin were used, one standard (Pharma Nostra Pharmaceutical Ingredients, Rio de Janeiro, RJ, Brazil) named standard (P), and the other commercial sample (A) (Sandoz, São Paulo-SP, Brazil) were used in the study.

Wells of $12 \mathrm{~mm}$ diameter were made into petri dishes containing Mueller Hinton agar prepared in advance. With a sterile swab, the C. albicans inoculum was evenly distributed over the surface of the agar, allowed to stand at room temperature for approximately 3 minutes. Fifty microliters of the positive and negative controls, as well as of each concentration of standard and

\section{RESULTS AND DISCUSSION}

It was observed that in DMSO, there was a complete dilution of simvastatin, but since DMSO is a potent inhibitor, only the stock solution $(2500 \mu \mathrm{g} / \mathrm{mL})$ was performed with this solvent, the other dilutions were made in purified water. In this test of the action of DMSO on simvastatin, it was observed that the dilution used did not interfere in the growth of the yeast.

In the well-agar agar diffusion assays, it was found that simvastatin inhibited the growth sample simvastatin $(78,156,312,625,1250$ $\mu \mathrm{g} \cdot \mathrm{mL}^{-1}$ ) were dispensed into each properly identified well using an automatic pipette. The plates were incubated for 24 hours at $35 \pm 1^{\circ} \mathrm{C}$ (RIOS; RECIO; VILLAR, 1988; VANDEN BERGHE; VLIETINCK, 1991; SILVEIRA et al, 2009). The tests were performed in triplicate.

The growth inhibition halo was measure in millimeters using a digital caliber. As negative control was used sterile water and fluconazole at $256 \mu \mathrm{g} \mathrm{mL}^{-1}$ as positive control. A test with DMSO diluted 1:1 in distilled water was also done to evaluate the action of the same on $C$. albicans.

The results of the biological assays were obtained using Student's $t$ test for each concentration, with post-test of Mann-Whitney, in the comparison between standard and sample, at the significance level of 5\% (RUXTON, 2006).

C. albicans, with formation of inhibition halos around the wells where the solutions tested were deposited.

In the comparison between sample and standard, both had similar behavior in inhibiting the growth of $C$. albicans. Table I presents the results of growth inhibition halos measurements of C. albicans for standard and sample simvastatin. 
Table I - Mean of halos measurement ( $\mathrm{mm}$ ) for sensitivity test by disc-diffusion method in agar

\begin{tabular}{c|cccc}
\hline \multicolumn{1}{c}{} & \multicolumn{4}{c}{$\begin{array}{c}\text { Mean } \pm \text { SD of halos measurement }(\mathrm{mm}) \\
\text { Candida albicans } 90028\end{array}$} \\
\hline \multirow{2}{*}{ Concentration of Simvastatin $\mu$ g.mL-1 } & Mean & SD & Mean & SD \\
\cline { 2 - 5 } & P & P & A & 0.058 \\
18 & 9.6 & 0.058 & 14.5 & 0.058 \\
312 & 13.3 & 0.1 & 16.8 & 0.115 \\
625 & 16.1 & 0.058 & 17.9 & 0.153 \\
1250 & 18.5 & 0.1 & 22 & 0.252 \\
Fluconazole $(\mathrm{C}+)$ & 22.9 & 0.058 & 24.5 & - \\
Purified water $(\mathrm{C}-)$ & 25 & & & \\
\hline
\end{tabular}

A: sample; C+: positive control; C-: negative control; P: standard; SD: standard deviation

As can be seen in Figure 1, there were no significant differences when comparing the standard with the sample on inhibition of the $C$. albicans ATCC strain, suggesting that both the pharmaceutical standard and the commercial sample have antimicrobial effect.

The objective of the microbiological assay was to evaluate the inhibition of growth of the microorganism by the simvastatin test and to evaluate the lowest concentration capable of achieving this inhibition. An advantage of this type of determination is that it does not require specialized and costly equipment and does not use solvents that are potentially toxic to the analyst and the environment (CARTER et al, 2017; DEGTYAREVA et al, 2017; COORENS et al, 2017).

P: standard; A: sample

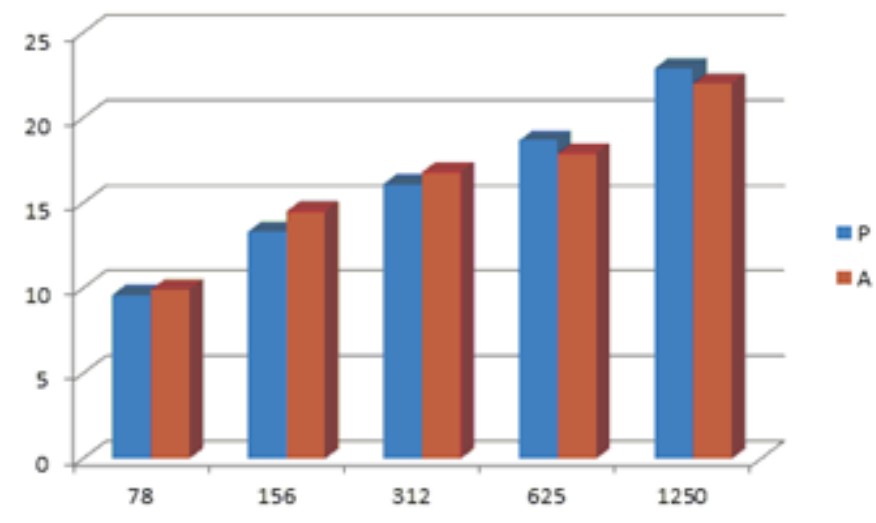

Figure 1: Comparison of growth inhibitory halos measurements for C. albicans ATCC 90028. P: standard and A: sample 
Technological progress, together with scientific knowledge, has made possible a greater sensitivity of diagnostic methods and, in a similar way, has facilitated the identification of a diversity of yeast species in the laboratory of clinical analyzes or clinical mycology that have decreased sensitivity and resistance to fluconazole, and reports of the occurrence of Candida spp. Resistance in vitro to the different antifungal agents, has increased the researchers interest in antifungal sensitivity monitoring of clinical isolates to predict clinical response to therapy, although resistance is still an uncommon phenomenon (THANGAMANI et al, 2015; ZHANG et al, 2016; MONROY-PÉREZ et al, 2016; MEIS et al, 2016; LEONARDELLI et al, 2017).

Statins are inhibitors of the enzyme 3 hydroxy - 3 - methyl - glutaryl - coenzyme A (HMG - CoA) reductase, leading to cholesterol production management (SLUYTER et al, 2016; SMITH et al. 2017; WADIA et al, 2017). Among the various statins, there is simvastatin, an HMGCoA reductase inhibitor, which has been widely used in clinical practice, in controlling cholesterol levels.

Thus, in addition to its lipid-lowering function, this statin is notable for other side effects, including anti-inflammatory (PETRIS; SOUZA; BORTOLETTO, 2016), immunomodulatory, antioxidant, as well as the promotion of angiogenesis and increased differentiation of osteoblasts, inducing bone formation (SANTOS; BARACHO, 2015). Such properties offer great potential for statins also to possess antimicrobial potential.

Several authors (CHAMILOS; LEWIS; KONTOYIANNIS, 2006; CABRAL;
FIGUEROA; FARIÑA, 2013) presented the association of simvastatin with other antibiotics, which considerably reduced the growth of endodontic microorganisms. They also investigated the antifungal action of statins on zygomycetes and observed considerable fungicidal activity in vitro against all seven Zygomycetes isolates tested. The inhibitory activity of simvastatin on the growth of Candida and Cryptococcus yeasts with an inhibitory effect against both planktonic cells and biofilms was demonstrated by Brilhante et al (2015). The MICs of simvastatin against $C$. albicans and $C$. tropicalis were similar to serum levels of the drug when administered to control blood cholesterol.

In the current research, the antimicrobial activity of simvastatin against Candida albicans ATCC 90028 was analyzed. It has been observed that simvastatin has an antifungal action against C. albicans and emphasizes its antifungal potential as described in other works (CABRAL; FIGUEROA; FARIÑA, 2013; BRILHANTE et al, 2015). The MIC results identified $78 \mu \mathrm{g} / \mathrm{mL}$ as the lowest concentration capable of inhibiting the growth of Candida albicans.

This action is possibly due to the inhibition of the enzyme $14 \alpha$-demethylase (14 DM), an important cytochrome P-450 enzyme in the ergosterol biosynthesis route, which catalyzes the oxidative removal of the $14 \alpha$-methyl group from lanosterol (ZHANG et al, 2016; NIWA; IMAGAWA, 2016; SUI et al, 2017). The blockade of simvastatin-induced ergosterol synthesis has been corroborated by bioassays by several authors, causing this statin to become a potential antifungal agent. 


\section{CONCLUSION}

The recommendations of the medicine help considerably in the search and selection of new pharmacological models to be used as an alternative to the conventional treatments. Given that the Candida genus is already resistant to azoles, the use of simvastatin as a potent growth inhibitor of these microorganisms appears as an alternative. The tests developed to evaluate the in vitro antimicrobial activity of simvastatin evidenced a capacity of inhibition of the growth of Candida albicans. With this evaluation and determination of the MIC, new perspectives are opened for the performance of pharmacokinetic studies in order to determine doses for in vivo research.

\section{FUNDING}

This work was supported by the UnifalMG, Capes, Fapemig.

\section{REFERENCES}

AHMAD, K; KHAN, MK; BAIG, MH; IMRAN, M; GUPTA, GK. Role of Azoles in cancer prevention and treatment: present and future perspectives. Anticancer Agents Med Chem. 2016; 16.

ALCAZAR-FUOLI, L; MELLADO, E. Ergosterol biosynthesis in Aspergillus fumigatus: its relevance as an antifungal target and role in antifungal drug resistance. Front Microbiol. 2013; 10(3): 439.

BRILHANTE, RSN; CAETANO, EP; OLIVEIRA, JS; CASTELO-BRANCO, DSCM; SOUZA, E; ALENCAR, LP et al. Simvastatin inhibits planktonic cells and biofilms of Candida and Cryptococcus species. Braz J Infect Dis. 2015; 19(5): 459-465.

CABRAL, ME; FIGUEROA, LI; FARIÑA, J.I. Synergistic antifungal activity of statin-azole associations as witnessed by Saccharomyces cerevisiaeand Candidautilis-bioassays and ergosterol quantification. Rev Iberoam Micol. 2013; 30(1): 31-8.
CAMPOY, S; ADRIO, JL. Antifungals. Biochem Pharmacol., 2017; 133:86-96.

CARTER, J; WEAVER, BA; CHIACCHIO, MA; MESSERSMITH, AR; LYNCH, WE; FESKE, BD et al. Synthesis, Stereochemical Characterization, and Antimicrobial Evaluation of a Potentially Nonnephrotoxic 3'-C-acethydrazide Puromycin Analog. Nucleosid Nucleot Nucleic Acids. 2017; 36(3):224241.

CHAMILOS, G; LEWIS, RE; KONTOYIANNIS, DP. Lovastatin has significant activity against zygomycetes and interacts synergistically with voriconazole. Antimicrob Agents Chemother. 2006; 50(1): 96-103.

CHENGE, JT; LE, DV; SWAMI, S; MCLEAN, KJ; KAVANAGH, ME; COYNE, AG et al. Structural Characterization and Ligand/Inhibitor Identification Provide Functional Insights into the Mycobacterium tuberculosis Cytochrome P450CYP126A1. J Biol Chem., 2017; 292(4): 1310-1329

Clinical and Laboratory Standard Institute. CLSI. Performance Standard for Antimicrobial Susceptibility Test: Approved Standard Twelfth Edition. CLSI document M02-A12 Wayne, PA, 2015.

COORENS, M; SCHEENSTRA, MR; VELDHUIZEN, EJ; HAAGSMAN, HP. Interspecies cathelicidin comparison reveals divergence in antimicrobial activity, TLR modulation, chemokine induction and regulation of phagocytosis. Scientific Reports 2017; 7: 40874.

DE MELLO, TP; DE SOUZA RAMOS L; BRAGASILVA, LA; BRANQUINHA, MH; DOS SANTOS, AL. Fungal Biofilm - A Real Obstacle against an Efficient Therapy: Lessons from Candida. Curr Top Med Chem. 2017; 17: 1987-2004.

DEGTYAREVA, NN; GONG, C; STORY, S; LEVINSON, N; OYELERE, AK; GREEN, KD et al. Antimicrobial Activity, AME Resistance and Translation Inhibition Studies of AnthraquinoneNeomycin Conjugates. ACS Infect Dis. 2017; 3(3):206215.

DEL POETA, M. Special Issue: Novel Antifungal Drug Discovery. J Fungi (Basel). 2016; 2:33.

HENNESSY, E; ADAMS, C; REEN, FJ; O'GARA, F. Is There Potential for Repurposing Statins as Novel Antimicrobials? Antimicrob Agents Chemother. 2016; 60(9): 5111-21.

LEONARDELLI, F; THEILL, L.; NARDIN, ME; MACEDO, D; DUDIUK, C; MENDEZ, E et al. First itraconazole resistant Aspergillus fumigatus clinical isolate harbouring a G54E substitution in Cyp51Ap in 
South America. Rev Iberoam Micol. 2017; 10: 11301406.

LONG, N; XU, X; ZENG, Q; SANG, H; LU, L. Erg4A and $\mathrm{Erg} 4 \mathrm{~B}$ are required for conidiation and azole resistance via regulation of ergosterol biosynthesis in Aspergillus fumigatus. Appl Environ Microbiol. 2016.

MACREADIE, IG; JOHNSON, G; SCHLOSSER, T; MACREADIE PI. Growth inhibition of Candida species and Aspergillus fumigatus by statins. FEMS Microbiol Lett. 2006; 262(1): 9-13

MEIS, JF; CHOWDHARY, A; RHODES, JL; FISHER, MC; VERWEIJ, PE. Clinical implications of globally emerging azole resistance in Aspergillus fumigatus. Philos Trans R Soc Lond B Biol Sci. 2016; 5(371): 1709.

MENEZES, EA; VASCONCELOS JÚNIOR, AA; SILVA, CL; PLUTARCO, FX; CUNHA, MC; CUNHA, FA. In vitro synergism of simvastatin and fluconazole against Candida species. Rev Ins Med Tropic São Paulo. 2012; 54(4): 197-199.

MONROY-PÉREZ, E; PANIAGUA-CONTRERAS, G L; RODRÍGUEZ-PURATA, P; VACA-PANIAGUA, F; VÁZQUEZ-VILLASEÑOR, M; DÍAZ-

VELÁSQUEZ, C. et al. High Virulence and Antifungal Resistance in Clinical Strains of Candida albicans. Can J Infect Dis Med Microbiol. 2016.

NIWA, T; IMAGAWA, Y. Substrate Specificity of Human Cytochrome P450 (CYP) 2C Subfamily and Effect of Azole Antifungal Agents on CYP2C8. J Pharm Pharm Sci. 2016; 19(4): 423-429.

PETRIS, AJ; SOUZA, RKT; BORTOLETTO, MSS. Public sector participation in the supply of dyslipidemia medication in a population-based study. Ciênc. saúde coletiva [online]. 2016; 21(12): 38993906.

RAHAL, EA; CONSTANTIN, WN; ZEIDAN, N; ABDELNOOR, AM. Atorvastatin Reduces the Survival of Candida albicans-Infected BALB/c Mice. Front Microbiol. 2015; 22(6): 1474.

RIOS, JL; RECIO, MC; VILLAR, A. Screening methods for natural products with antimicrobial activity: A review of the literature. $\mathrm{J}$ Ethnopharmacol. 1988; 23 (2-3): 127-149.

RUXTON, GD. The unequal variance t-test is an underused alternative to Student's 25 t-test and the Mann- Whitney U test. Behavioral Ecolog. 2006; 17: 688-690.

SANTOS, ALR; BARACHO, NCV. Efeitos do Tratamento Crônico com Sinvastatina na Função Renal de Ratos Submetidos a um Modelo Experimental de Doença Renal Crônica. Rev Ciênc Saúde. 2014; 4(2).

SILVEIRA, LM; OLEA, RSG; MESQUITA, JS; CRUZ, ALN; MENDES, JC. Antimicrobial activity methodologies applied to plants extracts: comparison between two agar diffusion techniques. Rev. Bras. Farm. 2009; 90(2): 124-128.

SLUYTER, JD; HUGHES, AD; LOWE, A; CAMARGO, CAJR; SCRAGG, R.K. Statin utilization in a real-world setting: a retrospective analysis in relation to arterial and cardiovascular autonomic function. Pharmacol Res Perspect. 2016, 22(4): e00276.

SMITH, A; MURPHY, L; BENNETT, K; BARRON, TI. Patterns of statin initiation and continuation in patients with breast or colorectal cancer, towards endof-life. Support Care Cancer, 2017; 25(5):1629-1637.

SUI, G; ZHANG, W; ZHOU, K; LI, Y; ZHANG, B; $\mathrm{XU}, \mathrm{D}$ et al. Trialkylamine Derivatives Containing a Triazole Moiety as Promising Ergosterol Biosynthesis Inhibitor: Design, Synthesis, and Antifungal Activity. Chem Pharm Bull. 2017; 65(1): 82-89.

SUTTON, CL; TAYLOR, ZE; FARONE, MB; HANDY, ST. Antifungal activity of substituted aurones. Bioorg Med Chem Lett. 2017; 27: 901-903.

THANGAMANI, S; MOHAMMAD, H; ABUSHAHBA, MFN; HAMED, M; SOBREIRA, TJ P; HEDRICK, VE.et al. Exploring simvastatin, an antihyperlipidemic drug, as a potential topical antibacterial agent. Scientific Reports. 2015; 5: 1-13.

TING, M; WHITAKER, EJ; ALBANDAR, JM. Systematic review of the in vitro effects of statins on oral and perioral microorganisms. Eur J Oral Sci. 2016; 124(1): 4-10.

TORRES, KA; LIMA, SM; UEDA, SM. Activity of the aqueous extract of Schinus terebinthifolius Raddi on strains of the Candida genus. Rev Bras Ginecol Obstet. 2016; 38:593-599.

VANDEN BERGHE, DA; VLIETINCK, AJ. Screening methods for antibacterial and antiviral agents from higher plants. In: Dey PM, Harbone JD, editor. Methods in Plant Biochemistry, Academic Press, London, 1991. p.47-69.

WADIA, SK; BELKIN, M; CHOW, K; NATTIV, J; APPIS, A; FEINSTEIN, S B et al. In-hospital statin underutilization among high-risk patients: delayed uptake of the 2013 cholesterol guidelines in a U.S. cohort. Hosp Pract (1995). 2017; 45(1):16-20. 
WARRILOW, AG; PRICE, CL; PARKER, JE;

ROLLEY, NJ; SMYRNIOTIS, CJ; HUGHES, DD et

al. Azole Antifungal Sensitivity of Sterol $14 \alpha-$

Demethylase (CYP51) and CYP5218 from Malassezia globosa. Sci Rep. 2016; 13(6): 27690.

ZHANG, W; SUI, G; LI, Y; FANG, M; YANG, X;

$\mathrm{MA}, \mathrm{X}$ et al. Synthesis and in Vitro Antifungal

Activities of Novel Benzamide Derivatives Containing

a Triazole Moiety. Chem Pharm Bull. 2016; 64(6):

616-24.

\begin{tabular}{l} 
Daniela Cristina de Macedo Vieira \\
Pós doutoranda em Ciências Farmacêuticas - \\
Universidade Federal de Alfenas \\
\hline
\end{tabular}

Josimary de Moraes Vasconcelos

Mestranda em Ciências Biológicas - Universidade

Federal de Alfenas

Patricia Aparecida Fernandes Alves

Graduanda em Biomedicina - Universidade Federal de Alfenas

Thalita Francielli Pereira

Graduanda em Biomedicina - Universidade Federal de Alfenas 